\title{
The broad spectrum of hantaviruses and their hosts in Central Europe
}

\author{
B. KLEMPA ${ }^{1,2}$, L. RADOSA ${ }^{2}$, D.H. KRUGER ${ }^{2}$
}

\begin{abstract}
${ }^{1}$ Institute of Virology, Slovak Academy of Sciences, Dúbravská cesta 9, 84505 Bratislava, Slovak Republic; ${ }^{2}$ Institute of Virology, Helmut-Ruska-Haus, Charité Medical School, Charitéplatz 1, 10117 Berlin, Germany
\end{abstract}

\begin{abstract}
Summary. - Hantaviruses are considered to be emerging viruses due to their increasing significance as human pathogens and their cyclic reappearance during outbreaks. Central Europe is an important endemic region for hantavirus infections. Reflecting the presence of all relevant small mammals serving as reservoir hosts, close to all recognized European hantaviruses occur also in Central Europe. Important human pathogens, Puumala and Dobrava-Belgrade viruses, are present and cause hemorrhagic fever with renal syndrome of various severities. Moreover, several of the newly recognized shrew- and mole-borne hantaviruses are present. In this review, we summarize current data on molecular detection of hantaviruses in reservoir hosts as well as on molecular epidemiology of human hantavirus infections in Central Europe.
\end{abstract}

Keywords: hantavirus; hemorrhagic fever with renal syndrome; rodent; shrew; Central Europe

\section{Contents:}

1. Introduction

2. Molecular evidence for rodent-borne hantaviruses in Central Europe

2.1 Puumala virus

2.2 Dobrava-Belgrade virus

2.3 Tula virus

3. Newly recognized hantaviruses associated with shrews and moles

4. Clinical epidemiology

5. Concluding remarks

\section{Introduction}

Hantaviruses (the genus Hantavirus, the family Bunyaviridae) are considered as emerging viruses due to their increasing significance as human pathogens and their cyclic reappearance during outbreaks. They cause two human zoonoses; hemorrhagic fever with renal syndrome (HFRS) and

E-mail: boris.klempa@savba.sk; phone: +421-2-59302465. Abbreviations: ASIV = Asikkala virus; $\mathrm{DOBV}=$ Dobrava Belgrade virus; HFRS = hemorrhagic fever with renal syndrome; NVAV = Nova virus; PUUV $=$ Puumala virus; SWSV $=$ Seewis virus; TULV = Tula virus hantavirus cardiopulmonary syndrome. Prominent examples of hantaviruses that cause human disease are Hantaan virus, Seoul virus, Dobrava-Belgrade virus (DOBV), and Puumala virus (PUUV) causing HFRS in Eurasia while Sin Nombre virus and Andes virus cause hantavirus cardiopulmonary syndrome in the Americas (Kruger et al., 2011). Recently, hantaviruses have also been found in Africa (Klempa et al., 2006, 2007, 2012; Kang et al., 2011; Weiss et al., 2012; Sumibcay et al., 2012; Meheretu et al., 2012) where they may also represent a significant public health threat (Klempa et al., 2010, 2012b).

Hantaviruses are transmitted to humans by aerosolized excreta of their natural hosts, mainly rodents of the family Muridae. Recently, several other small mammal groups were shown to be hosts of distinct hantaviruses, including shrews (the order Soricomorpha, the family Soricidae) (Klempa et al., 2007; Arai et al., 2007; Song et al., 2007a,b), moles (the order Soricomorpha, the family Talpidae) (Arai et al., 2008; Kang et al., 2009b,c), and most recently even bats (the order Chiroptera) (Weiss et al., 2012; Sumibcay et al., 2012; de Araujo et al., 2012).

Hantaviruses are considered host-specific, usually being associated with a single or a few closely related species as their reservoir hosts. This strong association between hantaviruses and their reservoir hosts is consequently reflected in their geographical distribution. In Europe, two geographical regions are usually considered as typical 
hantavirus endemic regions; Fenno-Scandinavia (due to highest annual numbers of human PUUV infections) and the Balkans (due to the most severe HFRS cases in Europe associated with DOBV). However, Central Europe is also a particularly important "hantavirus region" for several reasons: a) both European pathogenic hantaviruses, PUUV and DOBV are present, b) the number of human hantavirus infections has recently increased to an alarming number (particularly in Germany), c) two genotypes (lineages) of DOBV associated with different mice species are present, d) several novel hantaviruses associated with shrews and moles were recently described here.

The scope of this review is to summarize current data on the molecular detection of hantaviruses in reservoir hosts and molecular epidemiology of human hantavirus infections in Central Europe. Although broader definitions of the regions encompassing Central Europe exist, this review focuses on the following countries: Austria, Czech Republic, Germany, Hungary, Poland, Slovakia, and Switzerland (Fig. 1).

\section{Molecular evidence for rodent-borne hantaviruses in Central Europe}

\subsection{Puumala virus}

Bank voles (Myodes glareolus, formerly Clethrionomys glareolus) are the natural host of PUUV. Interestingly enough, the first fragment of a PUUV genome in Central Europe was amplified not from this natural reservoir but from a human source (Pilaski et al., 1994). The first partial PUUV sequence from a vole trapped in Austria was published 3 years later (Bowen et al., 1997). Meanwhile more extensive PUUV S and $\mathrm{M}$ segment sequences were characterized from Austrian voles (Aberle et al., 1999; Plyusnina et al., 2006). PUUV in M. glareolus has also been molecularly detected in Slovakia (Leitmeyer et al., 2001) and Hungary (Plyusnina et al., 2009).

In Germany, the detection of PUUV in a vole from the North-Western part of the country was reported in 1999 (Heiske et al., 1999). From various M. glareolus specimens sampled during or after a PUUV outbreak in the Bavarian Forest (South-East Germany) in 2004, molecular phylogenetic analyses have been carried out (Essbauer et al., 2006; Schilling et al., 2007; Mertens et al., 2011). At the same time, vole-derived PUUV nucleotide sequences were also collected from other parts of Germany (Essbauer et al., 2007; Schilling et al., 2007). During the large PUUV outbreaks in 2007 and 2010, comprehensive molecular analyses of PUUV strains from voles and patients were carried out which led to the definition of various molecular PUUV clades corresponding to different geographical regions in Germany (Hofmann et al., 2008; Ettinger et al., 2012; see chapter 4 of this review).

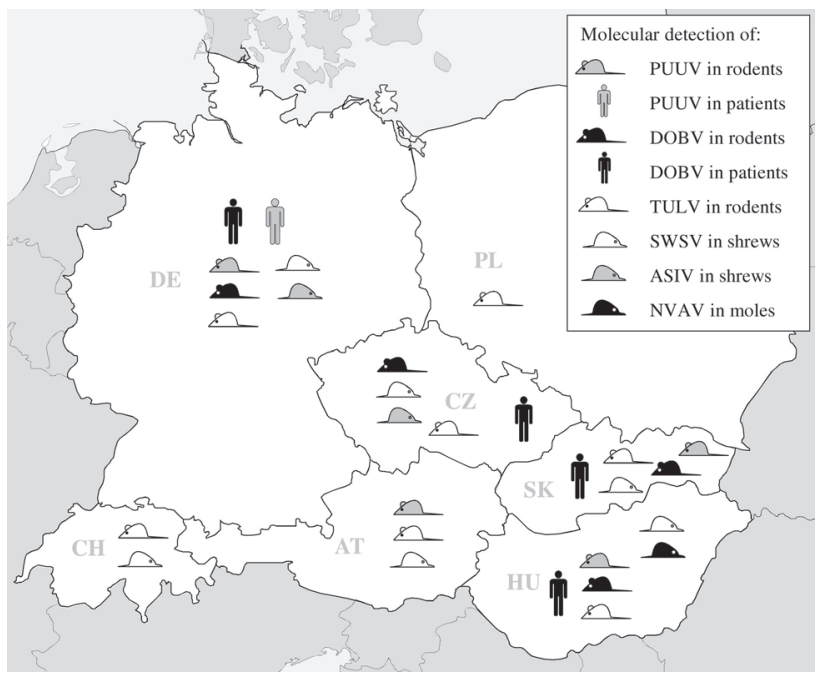

Fig. 1

Summarizing map of Central Europe indicating countries with molecularly documented presence of hantaviruses

AT, Austria; CH, Switzerland; CZ, Czech Republic; DE, Germany; HU, Hungary; PL, Poland; SK, Slovakia; ASIV, Asikkala virus; DOBV, DobravaBelgrade virus; NVAV, Nova virus; PUUV, Puumala virus; SWSV, Seewis virus; TULV, Tula virus.

Molecular comparisons of the different Central European PUUV strains are usually based on comparative analysis of partial S segment sequences. The strains fall into two main clades. First, PUUV strains from Germany and Slovakia form a clade which also includes strains from neighbouring Western European countries such as Belgium. The second clade consists of strains from Austria and Hungary which are phylogenetically related to PUUV strains from SouthEast Europe. As pointed out very recently, the molecular strain differentiation within these clades and their different subclades can be further advanced by detailed vole surveillance in the different geographical regions. The strict local distribution of bank voles enables an allocation of particular PUUV strains to defined geographical areas (Ettinger et al., 2012).

\subsection{Dobrava-Belgrade virus}

DOBV is hosted by mice of at least three species of the genus Apodemus. Molecular phylogenetic analyses have shown that DOBV forms four evolutionary lineages. One of these lineages, Saaremaa virus, is currently recognized as an independent virus species on the ICTV species list. Unfortunately, all strains associated with striped field mice (A. agrarius) are designated as Saaremaa virus by some authors regardless of their phylogenetic relationship with other DOBV lineages which often leads to confusion. In accordance with the four phylogenetic lineages, we have 
recently proposed a subdivision of the DOBV species into 4 genotypes, named Dobrava, Kurkino, Saaremaa, and Sochi according to the geographical place where the first strain of the genotype was molecularly detected (Klempa et al., 2013a) and will use this classification throughout this review.

Two of the defined genotypes, Dobrava (associated with yellow necked mouse, A. flavicollis) and Kurkino (associated with $A$. agrarius) have been molecularly detected in Central Europe. The first molecular evidence of the presence of DOBV in Central Europe was obtained from $A$. agrarius mice caught in Slovakia (Sibold et al., 1999b). In the follow-up study, A. agrarius- and A. flavicollis-specific virus lineages, now recognized as Kurkino and Dobrava genotypes, respectively, were found to be present sympatrically in Eastern Slovakia (Sibold et al., 2001) and thorough phylogenetic analyses suggested putative genetic interactions (homologous recombination and reassortment) in the evolution of the genotypes (Klempa et al., 2003b).

Two Central European DOBV-Kurkino cell culture isolates from mice allowing in vitro studies currently exist, one from Slovakia (Klempa et al., 2005) and the other from Germany (Popugaeva et al., 2012). In vitro studies with the German isolate showed that the virus uses cellular $\beta 3$ integrins and Decay Accelerating Factor as entry receptors as has also been shown for the highly pathogenic Hantaan virus. Recently, multiple spillover infections of $A$. agrarius-associated Kurkino genotype (=DOBV-Aa lineage) to A. flavicollis mice were reported in Germany (Schlegel et al., 2009) which might have important consequences in terms of putative genetic reassortment or stable host switch and spread of the virus to new regions where A. agrarius mice are absent.

The first molecular evidence that Kurkino genotype causes human HFRS cases was obtained in Germany when the phylogenetic analysis of DOBV sequence obtained from HFRS patient material showed that it belonged to the cluster of A. agrariusassociated strains (Klempa et al., 2004). In addition to Slovakia and Germany, in Central Europe the DOBV-Kurkino genotype has so far been detected only in Hungary (Scharninghausen et al., 1999; Jakab et al., 2007a; Plyusnina et al., 2009).

It is important to note that the Dobrava genotype of DOBV, associated with A. flavicollis mice and known to cause severe and fatal HFRS cases in South-East Europe, is also present in Central Europe. In Slovakia (Sibold et al., 2001) and Hungary (Plyusnina et al., 2009), Dobrava genotype was found to co-circulate with the Kurkino genotype. Most importantly, Dobrava genotype was shown to cause severe HFRS cases in the Czech Republic (Papa et al., 2010), Slovakia (Zelená et al., 2011), and in Hungary (Jakab et al., 2007b).

\subsection{Tula virus}

Tula virus (TULV) was initially associated with European common voles Microtus arvalis and M. rossiaemeridionalis caught in Russia (Plyusnin et al., 1994). In parallel, the virus was also found in M. arvalis voles caught in Slovakia (Sibold et al., 1995). Soon after, the first and so far only TULV cell culture isolate was obtained from $M$. arvalis vole trapped in the Czech Republic (Vapalahti et al., 1996).

Besides the aforementioned Slovakia and Czech Republic, TULV has also been molecularly detected in Austria (Bowen et al., 1997), Germany (Klempa et al., 2003a), Poland (Song et al., 2004), Hungary (Jakab et al., 2008), and Switzerland (Schlegel et al., 2012a). Interestingly, phylogenetic analysis of TULV strains from Western and Eastern Slovakia revealed the existence of two distinct virus lineages and indicated putative homologous recombination event in the evolution of the Eastern Slovakian strains (Sibold et al., 1999a). In general, TULV strains from Central Europe show a remarkable degree of divergence and can be assigned to several clades across the TULV phylogenetic tree (as shown in, e.g., Schlegel et al., 2012a) suggesting multiple introductions and long term survival of the virus in the region.

Recent studies from Germany and Switzerland have indicated that TULV is less host-specific than for hantaviruses generally assumed and that several other species of voles from Microtus genus, such as M. agrestis (Schmidt-Chanasit et al., 2010), but also from different genus, such as Arvicola amphibious (Schlegel et al., 2012a), might serve as TULV reservoir hosts.

\section{Newly recognized hantaviruses associated with shrews and moles}

Since 2007, knowledge on hantavirus host range has been notably revised through the identification of numerous new shrew- and mole-associated hantaviruses. Several of them were identified or later detected also in Central Europe. These new hantaviruses share very low sequence similarity with rodent-borne viruses. There is most likely no serological cross-reactivity with the 'old' hantaviruses explaining why these viruses remained undetected for such a long period of time. The human pathogenic potential of these viruses is therefore currently unknown and remains to be determined.

Seewis virus (SWSV), the first European shrew-borne hantavirus was identified in the European common shrew (Sorex araneus) caught near Seewis village in Switzerland (Song et al., 2007a). Later on, SWSV was detected in S. araneus shrews captured in Finland and Hungary (Kang et al., 2009a) as well as and in Austria and Germany (EU418604-16; Nowotny et al., unpublished data). Extensive phylogenetic study of Schlegel et al. (2012b) focusing on Germany, the Czech Republic and Slovakia confirmed a wide geographic distribution of SWSV across Europe and indicated high genetic divergence and strong geographical 
clustering of the virus in local shrew populations. European common shrew is regarded as the main reservoir of SWSV, however other species such as Pygmy shrew (S. minutus) and Mediterranean or Miller's water shrew (Neomys anomalus) have been shown to carry SWSV, too, probably only in the form of random and transient, so called "spill-over" infections (Schlegel et al., 2012b).

Very recently, Asikkala virus (ASIV) has been described in pygmy shrews (S. minutus) as a second shrew-borne hantavirus in Central Europe. Currently available genomic data is derived from two shrew samples from the Czech Republic and one from Germany (Radosa et al., 2013; Fig. 2).

In 2009, a new and highly divergent hantavirus was described in samples from European common mole (Talpa europaea) from the Zala region of Hungary and was designated as Nova virus (NVAV) (Kang et al., 2009c). NVAV is the first and, until now, only mole-borne hantavirus present in Europe. European common mole is widely dispersed throughout Europe and covers the complete area of Central Europe. Phylogenic analysis revealed that NVAV belongs to the highly divergent group of shrew-, bat-, and mole-borne hantaviruses with the batassociated Mouyassué virus from Africa currently recognized as the most closely related virus (Sumibcay et al., 2012). Available amino acid sequences of the nucleocapsid and polymerase proteins show remarkably low similarity (50-60\%, respectively) with other hantaviruses (Kang et al., 2009c).

Nucleotide sequences of yet another putative new Central European shrew-borne virus recently appeared in GenBank (Acc. No. JX990964-66; Gu et al., unpublished data). The virus, designated as Boginia virus, was found in two Eura-

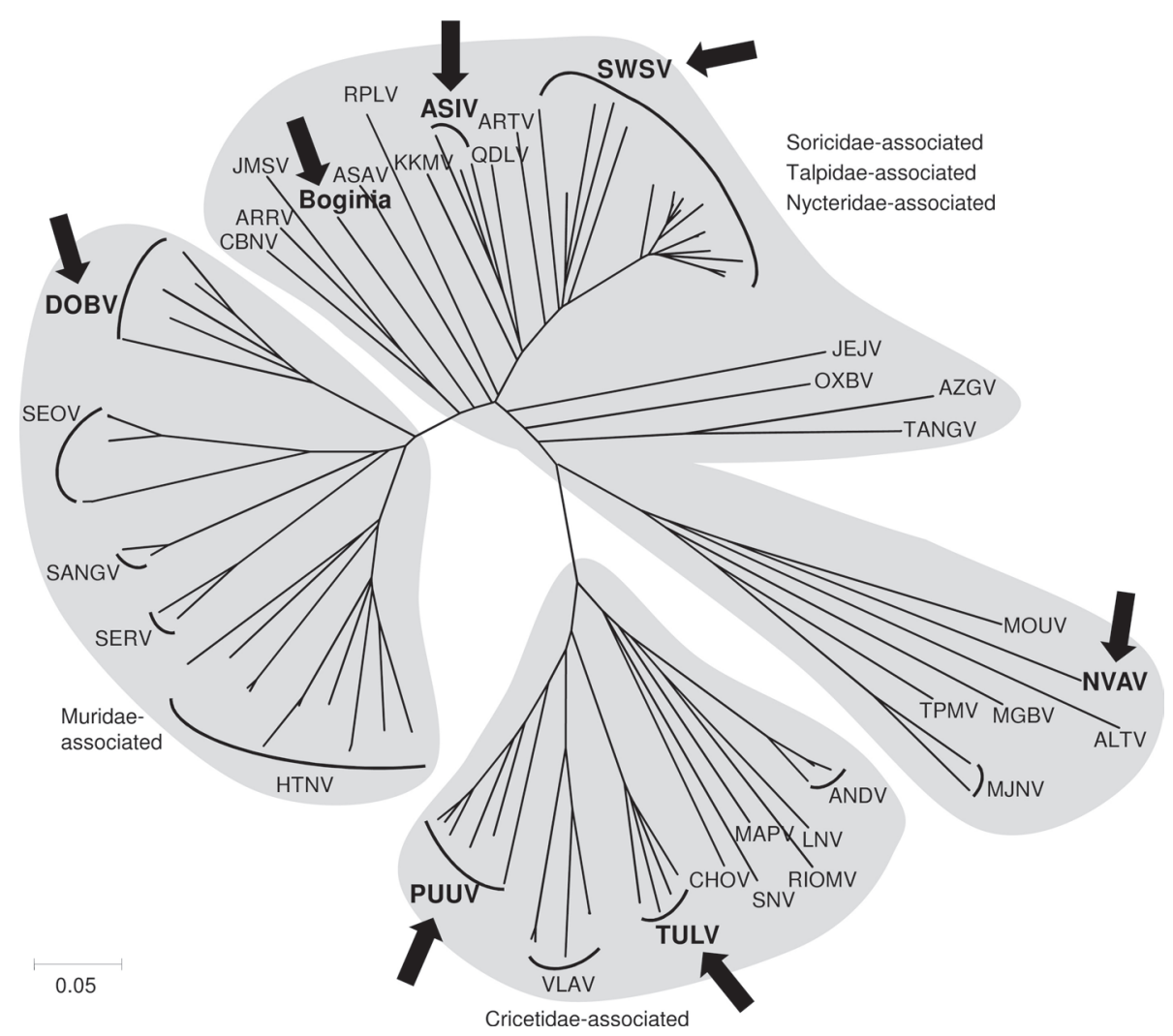

Fig. 2

Hantavirus phylogenetic tree illustrating high divergence of hantaviruses detected in Central Europe

Hantaviruses detected in Central Europe are marked by black arrows. The grey shaded areas indicate association of hanta viruses with reservoir host families. The phylogenetic tree was constructed on the basis of partial L segment sequences (352 nucleotides) in the MEGA5 program (Tamura et al., 2011) by using the Neighbor-Joining method with Maximum Composite Likelihood method applied to calculate the evolutionary distances. Scale bar indicates an evolutionary distance of 0.05 substitutions per position in the sequence.

ALTV, Altai virus; ANDV, Andes virus; ARRV, Ash River virus; ARTV, Artybash virus; ASAV, Asama virus; ASIV, Asikkala virus; AZGV, Azagny virus; CBNV, Cao Bang virus; CHOV, Choclo virus; DOBV, Dobrava-Belgrade virus; HTNV, Hantaan virus; JEJV, Jeju virus; JMSV, Jemez Springs virus; KKMV, Kenkeme virus; LNV, Laguna Negra virus; MAPV, Maporal virus; MGBV, Magboi virus; MJNV, Imjin virus; MOUV, Mouyassué virus; NVAV, Nova virus; OXBV, Oxbow virus; PUUV, Puumala virus; QDLV, Qiandao Lake virus; RIOMV, Rio Mamore virus; RPLV, Camp Ripley virus; SANGV, Sangassou virus; SEOV, Seoul virus; SERV, Serang virus; SWSV, Seewis virus; SNV, Sin Nombre virus; TGNV, Tanganya virus; TPMV, Thottapalayam virus; TULV, Tula virus; VLAV, Vladivostok virus. 
Table 1. Hantaviruses molecularly demonstrated to be present in Central Europe

\begin{tabular}{|c|c|c|c|c|c|c|}
\hline Virus & $\begin{array}{l}\text { Puumala virus } \\
\text { (PUUV) }\end{array}$ & $\begin{array}{l}\text { Dobrava Belgrade } \\
\text { virus (DOBV) }\end{array}$ & $\begin{array}{l}\text { Tula virus } \\
\text { (TULV) }\end{array}$ & $\begin{array}{l}\text { Seewis virus } \\
\text { (SWSV) }\end{array}$ & $\begin{array}{l}\text { Asikkala virus } \\
\text { (ASIV) }\end{array}$ & $\begin{array}{l}\text { Nova virus } \\
\text { (NVAV) }\end{array}$ \\
\hline Host $(\mathrm{s})^{*}$ & Myodes glareolus & $\begin{array}{l}\text { Apodemus agrarius } \\
\text { A. flavicollis }\end{array}$ & $\begin{array}{l}\text { Microtus arvalis } \\
\text { M. agrestis } \\
\text { Arvicola amphibius }\end{array}$ & $\begin{array}{l}\text { Sorex araneus } \\
\text { S. minutus } \\
\text { Neomys anomalus }\end{array}$ & Sorex minutus & Talpa europea \\
\hline \multicolumn{7}{|c|}{ Detection in Central Europe (First report for a given country) } \\
\hline Austria & Bowen et al. (1997) & - & Bowen et al. (1997) & EU418604-6 & - & - \\
\hline Czech Republic & - & Papa et al. (2010) & $\begin{array}{l}\text { Plyusnin et al. } \\
\text { (1995) }\end{array}$ & $\begin{array}{l}\text { Schlegel et al. } \\
(2012 \mathrm{~b})\end{array}$ & Radosa et al. (2013) & - \\
\hline Germany & Pilaski et al. (1994) & $\begin{array}{l}\text { Klempa et al. } \\
(2004)\end{array}$ & $\begin{array}{l}\text { Klempa et al. } \\
(2003)\end{array}$ & $\begin{array}{l}\text { Schlegel et al. } \\
(2012 \mathrm{~b})\end{array}$ & Radosa et al. (2013) & - \\
\hline Hungary & $\begin{array}{l}\text { Plyusnina et al. } \\
\text { (2009) }\end{array}$ & $\begin{array}{l}\text { Scharninghausen et } \\
\text { al. (1999) }\end{array}$ & Jakab et al. (2008) & Kang et al. (2009a) & - & Kang et al. (2009c) \\
\hline Poland & - & - & Song et al. (2004) & - & - & - \\
\hline Slovakia & $\begin{array}{l}\text { Leitmeyer et al. } \\
(2001)\end{array}$ & $\begin{array}{l}\text { Sibold et al. } \\
\text { (1999b) }\end{array}$ & Sibold et al. (1995) & $\begin{array}{l}\text { Schlegel et al. } \\
(2012 \mathrm{~b})\end{array}$ & - & - \\
\hline Switzerland & - & - & $\begin{array}{l}\text { Schlegel et al. } \\
(2012 \mathrm{a})\end{array}$ & Song et al. (2007a) & - & - \\
\hline
\end{tabular}

"Virus detection in these species has been reported in Central Europe but they are not necessarily the virus primary reservoir hosts in all cases.

sian water shrews (Neomys fodiens) in Poland but further information is currently not available.

\section{Clinical epidemiology}

Hantavirus infections in their respective host animals seem to be persistent and without obvious harm to the animal. In contrast, "spill-over" infections of humans proceed as acute disease in 10-20\% of cases after primary infection of immune-naïve persons (clinical manifestation index). The pathogenesis of hantavirus disease is characterized by vasodilatation and barrier impairment of the vascular endothelium as well as disturbances in blood coagulation (Kruger et al., 2011). Consequently, inflammatory processes occur in organs such as kidney und lung. In continents outside America, hantavirus disease is also named hemorrhagic fever with renal syndrome (HFRS). In addition, the term nephropathia epidemica is sometimes used for mild forms of HFRS caused by PUUV infections.

Of the Central European countries, the following numbers of HFRS cases per year were reported between 2005 and 2009 (minimum-maximum); Austria 12-78 cases / Czech Republic 2-7 cases / Germany 72-1,688 cases / Hungary 6-16 cases / Poland 3-17 cases / Slovakia 3-22 cases / Switzerland 0-1 case (Heyman et al., 2011). However, one can expect serious underreporting since in many clinical cases, doctors are not aware of this disease and do not initiate specific virological diagnostics. Moreover, the assays for primary and confirmatory serodiagnostics are not standardized and the results are not comparable Europe-wide. This is also true for the diagnostic methods used for serosurveillance studies in the different countries.

It is known that antibody cross-reactivity between different hantaviruses complicates the typing of the hantavirus which infected patients (Schilling et al., 2007). Therefore seroassays based on the detection of (non-neutralizing) antibodies against the immunodominant nucleocapsid protein do not always allow an unequivocal statement about the hantavirus species involved in the infection. Only molecular genetic methods enable the clear identification of hantavirus species and strains. Unfortunately, the use of those methods based on a RT-PCR approach is hampered by the fact that virus RNA is present in patients' blood only during the first few weeks after the onset of disease.

The first "Central European" PUUV-specific nucleotide sequence in a patient was detected about 20 years ago in Germany (Pilaski et al., 1994). More comprehensive PUUV sequence data from human sources was collected in Germany during outbreaks in 2004 (Schilling et al., 2007) and 2007 (Hofmann et al., 2008). Over the last few years, HFRS cases in Germany have reached new record values with more than 2,000 reported cases in 2010 and 3,000 cases in 2012 (Robert Koch-Institut, http://www3.rki.de/SurvStat). A country-wide alert network was established and enabled the assessment of serum samples from PUUV-infected patients during the early (viraemic) clinical phase. The data showed that amplified nucleotide sequences of human origin from the different outbreak regions in Germany resemble sequences derived from the local $M$. glareolus animals. Coinciding sequences of human and vole origin 
formed different molecular PUUV clades corresponding to the different outbreak regions. These findings allow for the establishment of a molecular registry of PUUV strains in Germany, the exact allocation of the geographic site where a certain patient became infected, and the generation of risk maps for infection (Ettinger et al., 2012).

From Austria, there are two anecdotal reports about detection of PUUV nucleotide sequences in patients with acute renal failure and pulmonary oedema (Fakhrai et al., 2011) and another patient suffering from multiorgan failure (Hoier et al., 2006). Since the natural PUUV host, M. glareolus, is present in all Central European countries, one can expect human PUUV infections in these countries, too.

In general, the case fatality of PUUV-HFRS is thought to range between 0.1-0.4\% (Hjertqvist et al., 2010; Kruger et al., 2011). About $5 \%$ of hospitalized patients require temporary haemodialysis (Krautkramer et al., 2012).

Human infections by DOBV in Central Europe are caused by two DOBV lineages; genotype Dobrava carried by the yellow-necked mouse, Apodemus flavicollis, and genotype Kurkino, hosted by the striped field mouse, $A$. agrarius (Klempa et al., 2013; Kruger and Klempa, 2011; Papa, 2012). Most human infections by DOBV-Dobrava occur in South-East Europe, however they have also been occasionally reported from Central European countries. Molecular evidence in HFRS patients exists from the Czech Republic (Papa et al., 2010), Slovakia (Zelena et al., 2011; our unpublished data) and Hungary (Jakab et al., 2007b). Human infections by DOBV-Kurkino in Central Europe were molecularly demonstrated in North-East Germany (Klempa et al., 2004; Hofmann et al., unpublished data). The natural host of DOBV-Kurkino, A. agrarius, is prevalent in Central Europe with North-East Germany as the western border of its distribution. This explains why DOBV-Kurkino infections are registered in this region but not in South or West Germany. Since DOBV-Kurkino has been found in $A$. agrarius animals from different Central European countries (see above), one can also expect its future molecular detection in patients outside of Germany.

From the clinical point of view, different human virulence of the two DOBV genotypes must be mentioned. Infections by DOBV-Dobrava in the Balkans cause moderate to severe disease with case fatality rates of $10-12 \%$, whereas our investigations of large HFRS outbreaks in Russia due to DOBV-Kurkino infections showed mild to moderate courses with $0.3-0.9 \%$ case fatality (Dzagurova et al., 2009; Klempa et al., 2013a; Papa, 2012).

The pathogenicity towards humans of the third rodentborne hantavirus from Central Europe, Tula virus (TULV), is less clear. One human HFRS case has been reported with neutralizing antibodies best reactive against TULV and molecular detection of TULV sequences in $M$. arvalis mice from the environment of the patient, however no direct molecular evidence exists for human disease caused by TULV infection (Klempa et al., 2003a).

\section{Concluding remarks}

Central Europe is undoubtedly an important endemic region for hantavirus infections. Practically all European hantaviruses described so far also occur in Central Europe (Table 1) which is directly connected with the presence of all relevant small mammals as hantavirus hosts. Both important human pathogens, PUUV and DOBV are present and cause HFRS of various severities. In the case of DOBV, two distinct host-specific genotypes exist sympatrically and are shown to cause human diseases of distinct clinical severity. Based on recent epidemiological trends, it might be expected that Central Europe will face increasing numbers of HFRS cases in the form of disease outbreaks (as seen in recent years in Germany) and one can anticipate the identification of new hantaviruses in non-rodent hosts. The public health relevance of these newly recognized shrew- and mole-borne hantaviruses, not only in Central Europe, still needs to be determined. The progress in Central Europe in terms of development and research of hantavirus diagnostics, molecular epidemiology, and pathogenesis, treatment will advance the field of hantavirus research in general.

Acknowledgement. This work was supported by Deutsche Forschungsgemeinschaft (Research Training Group 1121 and grant No. KR1293/13-1), European Commission (European Virus Archive, FP7 CAPACITIES project - GA n ${ }^{\circ} 228292$ ), and the Slovak Research and Development Agency (contract No. APVV-0267-10).

Conflict of interest. The authors declare that there is no conflict of interest with the ideas put forward in the final version of manuscript.

\section{References}

Aberle SW, Lehner P, Ecker M, Aberle JH, Arneitz K, Khanakah G, Radda A, Radda I, Popow-Kraupp T, Kunz C, Heinz FX, J. Clin. Microbiol. Infect. Dis. 18, 467-472, 1999. http:// dx.doi.org/10.1007/s100960050325

Arai S, Song JW, Sumibcay L, Bennett SN, Nerurkar VR, Parmenter C, Cook JA, Yates TL, Yanagihara R, Emerg. Infect. Dis. 13, 1420-1423, 2007. http://dx.doi.org/10.3201/ eid1309.070484

Arai S, Ohdachi SD, Asakawa M, Kang HJ, Mocz G, Arikawa J, Okabe N, Yanagihara R, Proc. Natl. Acad. Sci. USA 105, 16296-16301, 2008. http://dx.doi.org/10.1073/ pnas.0808942105

Bowen MD, Gelbmann W, Ksiazek TG, Nichol ST, Nowotny N, J. Med. Virol. 53, 174-181, 1997. http://dx.doi. org/10.1002/(SICI)1096-9071(199710)53:2<174::AIDIMV11>3.0.CO;2-I 
de Araujo J, Thomazelli LM, Henriques DA, Lautenschalager D, Ometto T, Dutra LM, Aires CC, Favorito S, Durigon EL, BMC Res. Notes 5, 690, 2012. http://dx.doi. org/10.1186/1756-0500-5-690

Dzagurova TK, Klempa B, Tkachenko EA, Slyusareva GP, Morozov VG, Auste B, Kruger DH, J. Clin. Microbiol. 47, 40294036, 2009. http://dx.doi.org/10.1128/JCM.01225-09

Essbauer S, Schmidt J, Conraths FJ, Friedrich R, Koch J, Hautmann W, Pfeffer M, Wölfel R, Finke J, Dobler G, Ulrich R, Epidemiol. Infect. 134, 1333-1344, 2006. http://dx.doi. org/10.1017/S0950268806006170

Essbauer SS, Schmidt-Chanasit J, Madeja EL, Wegener W, Friedrich R, Petraityte R, Sasnauskas K, Jacob J, Koch J, Dobler G, Conraths FJ, Pfeffer M, Pitra C, Ulrich RG, Emerg. Infect. Dis. 13, 1271-1273, 2007. http://dx.doi.org/10.3201/ $\underline{\text { eid } 1308.061425}$

Ettinger J, Hofmann J, Enders M, Tewald F, Oehme RM, Rosenfeld UM, Ali HS, Schlegel M, Essbauer S, Osterberg A, Jacob J, Reil D, Klempa B, Ulrich RG, Kruger DH, Emerg. Infect. Dis. 18, 1461-1464, 2012. http://dx.doi.org/10.3201/ eid1809.111447

Fakhrai N, Mueller-Mang C, El-Rabadi K, Böhmig GA, Herold CJ, J. Thorac. Imaging 26, W51-53, 2011. http://dx.doi. org/10.1097/RTI.0b013e3181d29dfd

Heiske A, Anheier B, Pilaski J, Volchkov VE, Feldmann H, Virus Res. 61, 101-112, 1999. http://dx.doi.org/10.1016/S01681702(99)00024-6

Heyman P, Ceianu CS, Christova I, Tordo N, Beersma M, João Alves M, Lundkvist A, Hukic M, Papa A, Tenorio A, Zelená H, Essbauer S, Visontai I, Golovljova I, Connell J, Nicoletti L, Van Esbroeck M, Gjeruldsen Dudman S, Aberle SW, Avšić-Županc T, Korukluoglu G, Nowakowska A, Klempa B, Ulrich RG, Bino S, Engler O, Opp M, Vaheri A, Euro Surveill. 16, pii=19961, 2011.

Hjertqvist M, Klein SL, Ahlm C, Klingstrom J, Emerg. Infect. Dis. 16, 1584-1586, 2010. http://dx.doi.org/10.3201/ $\underline{\text { eid1610.100242 }}$

Hofmann J, Meisel H, Klempa B, Vesenbeckh SM, Beck R, Michel D, Schmidt-Chanasit J, Ulrich RG, Grund S, Enders, Kruger DH, Emerg. Infect. Dis. 14, 850-852, 2008. http://dx.doi. org/10.3201/eid1405.071533

Hoier S, Aberle SW, Langner C, Schnedl W, Högenauer C, Reisinger EC, Krejs GJ, Krause R, Emerg. Infect. Dis. 12, 356-357, 2006. http://dx.doi.org/10.3201/eid1202.050634

Jakab F, Horváth G, Ferenczi E, Sebok J, Varecza Z, Szucs G, Virus Res. 128, 149-152, 2007a. http://dx.doi.org/10.1016/j. virusres.2007.04.015

Jakab F, Sebok J, Ferenczi E, Horváth G, Szucs G, Scand. J. Infect. Dis. 39, 902-906, 2007b. http://dx.doi. org/10.1080/00365540701387072

Jakab F, Horváth G, Ferenczi E, Sebok J, Szucs G, Arch. Virol. 153, 20932096, 2008. http://dx.doi.org/10.1007/s00705-008-0216-5

Kang HJ, Arai S, Hope AG, Song JW, Cook JA, Yanagihara R, Virol. J. 6, 208, 2009a. http://dx.doi.org/10.1186/1743422X-6-208

Kang HJ, Bennett SN, Dizney L, Sumibcay L, Arai S, Ruedas LA, Song JW, Yanagihara R, Virology 388, 8-14, 2009b. http:// dx.doi.org/10.1016/j.virol.2009.03.019
Kang HJ, Bennett SN, Sumibcay L, Arai S, Hope AG, Mocz G, Song JW, Cook JA, Yanagihara R, PLoS One 4, e6149, 2009c. http://dx.doi.org/10.1371/journal.pone.0006149

Kang HJ, Kadjo B, Dubey S, Jacquet F, Yanagihara R, Virol. J. 8, 373, 2011. http://dx.doi.org/10.1186/1743-422X-8-373

Klempa B, Meisel H, Räth S, Bartel J, Ulrich R, Krüger DH, J. Clin. Microbiol. 41, 4894-4897, 2003a. http://dx.doi. org/10.1128/JCM.41.10.4894-4897.2003

Klempa B, Schmidt HA, Ulrich R, Kaluz S, Labuda M, Meisel H, Hjelle B, Krüger DH, J. Virol. 77, 804-809, 2003b. http:// dx.doi.org/10.1128/JVI.77.1.804-809.2003

Klempa B, Schütt M, Auste B, Labuda M, Ulrich R, Meisel H, Krüger DH, J. Clin. Microbiol. 42, 1322-1325, 2004. http://dx.doi. org/10.1128/JCM.42.3.1322-1325.2004

Klempa B, Stanko M, Labuda M, Ulrich R, Meisel H, Krüger DH, J. Clin. Microbiol. 43, 2756-2763, 2005. http://dx.doi. org/10.1128/JCM.43.6.2756-2763.2005

Klempa B, Fichet-Calvet E, Lecompte E, Auste B, Aniskin V, Meisel H, Denys C, Koivogui L, ter Meulen J, Krüger DH, Emerg. Infect. Dis. 12, 838-840, 2006. http://dx.doi.org/10.3201/ eid1205.051487

Klempa B, Fichet-Calvet E, Lecompte E, Auste B, Aniskin V, Meisel H, Barrière P, Koivogui L, ter Meulen J, Krüger DH, Emerg. Infect. Dis. 13, 520-522, 2007. http://dx.doi. org/10.3201/eid1303.061198

Klempa B, Koivogui L, Sylla O, Koulemou K, Auste B, Krüger DH, ter Meulen J, J. Infect. Dis. 201, 1031-1034, 2010. http:// dx.doi.org/10.1086/651169

Klempa B, Witkowski PT, Popugaeva E, Auste B, Koivogui L, Fichet-Calvet E, Strecker T, Ter Meulen J, Krüger DH, J. Virol. 86, 3819-3827, 2012. http://dx.doi.org/10.1128/ JVI.05879-11

Klempa B, Avsic-Zupanc T, Clement J, Dzagurova TK, Henttonen H, Heyman P, Jakab F, Kruger DH, Maes P, Papa A, Tkachenko EA, Ulrich RG, Vapalahti O, Vaheri A, Arch. Virol. 158, 521-529, 2013a. http://dx.doi.org/10.1007/ $\underline{\text { s00705-012-1514-5 }}$

Klempa B, Koulemou K, Auste B, Emmerich P, Thomé-Bolduan C, Günther S, Koivogui L, Krüger DH, Fichet-Calvet E, Trop. Med. Int. Health. 18, 366-371. 2013b.

Krautkramer E, Kruger DH, Zeier M, Kidney Int. 82, 1243-1245, 2012. http://dx.doi.org/10.1038/ki.2012.359

Kruger DH, Klempa B, In Liu D (Ed): Molecular Detection of Human Viral Pathogens. CRC Press, Boca Raton, pp. 631-638, 2011.

Kruger DH, Schonrich G, Klempa B, Hum. Vaccin. 7, 685-693, 2011. http://dx.doi.org/10.4161/hv.7.6.15197

Leitmeyer K, Sibold C, Meisel H, Ulrich R, Labuda M, Krüger DH, Virus Genes 23, 165-169, 2001. http://dx.doi. org/10.1023/A:1011840104037

Meheretu Y, Cížková D, Těšíková J, Welegerima K, Tomas Z, Kidane D, Girmay K, Schmidt-Chanasit J, Bryja J, Günther S, Bryjová A, Leirs H, Goüy de Bellocq J, Emerg. Infect. Dis. 18, 2047-2050, 2012. http://dx.doi.org/10.3201/ eid1812.120596

Mertens M, Kindler E, Emmerich P, Esser J, Wagner-Wiening C, Wölfel R, Petraityte-Burneikiene R, Schmidt-Chanasit J, Zvirbliene A, Groschup MH, Dobler G, Pfeffer M, Heckel 
G, Ulrich RG, Essbauer SS, Virus Genes 43, 177-791, 2011. http://dx.doi.org/10.1007/s11262-011-0620-x

Papa A, Antiviral Res. 95, 104-117, 2012. http://dx.doi.org/10.1016/j. antiviral.2012.05.011

Papa A, Zelená H, Barnetová D, Petrousová L, Clin. Microbiol. Infect. 16, 1187-1190, 2010. http://dx.doi.org/10.1111/ j.1469-0691.2009.03075.x

Pilaski J, Feldmann H, Morzunov S, Rollin PE, Ruo SL, Lauer B, Peters CJ, Nichol ST, J. Infect. Dis. 170, 1456-1462, 1994. http://dx.doi.org/10.1093/infdis/170.6.1456

Plyusnin A, Vapalahti O, Lankinen H, Lehväslaiho H, Apekina N, Myasnikov Y, Kallio-Kokko H, Henttonen H, Lundkvist A, Brummer-Korvenkontio M, Gavrilovskaya I, Vaheri A, J. Virol. 68, 7833-7839, 1994.

Plyusnin A, Cheng Y, Vapalahti O, Pejcoch M, Unar J, Jelinkova Z, Lehväslaiho H, Lundkvist A, Vaheri A, Virus Res. 39, 237-250, 1995. http://dx.doi.org/10.1016/01681702(95)00086-0

Plyusnina A,AberleSW, AberleJH, Plyusnin A,Scand.J.Infect.Dis. 38,512519, 2006. http://dx.doi.org/10.1080/00365540600585040

Plyusnina A, Ferenczi E, Rácz GR, Nemirov K, Lundkvist A, Vaheri A, Vapalahti O, Plyusnin A, J. Med. Virol. 81, 2045-2052, 2009. http://dx.doi.org/10.1002/jmv.21635

Popugaeva E, Witkowski PT, Schlegel M, Ulrich RG, Auste B, Rang A, Krüger DH, Klempa B, PLoS One 7, e35587, 2012. http://dx.doi.org/10.1371/journal.pone.0035587

Radosa L, Schlegel M, Gebauer P, Ansorge H, Heroldová M, Jánová E, Stanko M, Mošanský L, Fričová J, Pejčoch M, Suchomel J, Purchart L, Groschup MH, Krüger DH, Ulrich RG, Klempa B, Detection of shrew-borne hantavirus in Eurasian pygmy shrew (Sorex minutus) in Central Europe. Infect. Genet. Evol. 2013 (in press).

Scharninghausen JJ, Meyer H, Pfeffer M, Davis DS, Honeycutt RL, Emerg. Infect. Dis. 5, 468-470, 1999. http://dx.doi. org/10.3201/eid0503.990324

Schilling S, Emmerich P, Klempa B, Auste B, Schnaith E, Schmitz H, Kruger DH, Günther S, Meisel H, J. Clin. Microbiol. 45, 3008-3014, 2007. http://dx.doi.org/10.1128/ JCM.02573-06

Schlegel M, Klempa B, Auste B, Bemmann M, Schmidt-Chanasit J, Büchner T, Groschup MH, Meier M, BalkemaBuschmann A, Zoller H, Krüger DH, Ulrich RG, Emerg. Infect. Dis. 15, 2017-2020, 2009. http://dx.doi. org/10.3201/eid1512.090923

Schlegel M, Kindler E, Essbauer SS, Wolf R, Thiel J, Groschup MH, Heckel G, Oehme RM, Ulrich RG, Vector Borne Zoonotic Dis. 12, 503-513, 2012a. http://dx.doi.org/10.1089/ vbz.2011.0784

Schlegel M, Radosa L, Rosenfeld UM, Schmidt S, Triebenbacher C, Löhr PW, Fuchs D, Heroldová M, Jánová E, Stanko M,
Mošanský L, Fričová J, Pejčoch M, Suchomel J, Purchart L, Groschup MH, Krüger DH, Klempa B, Ulrich RG, Virus Genes 45, 48-55, 2012b. http://dx.doi.org/10.1007/ s11262-012-0736-7

Schmidt-Chanasit J, Essbauer S, Petraityte R, Yoshimatsu K, Tackmann K, Conraths FJ, Sasnauskas K, Arikawa J, Thomas A, Pfeffer M, Scharninghausen JJ, Splettstoesser W, Wenk M, Heckel G, Ulrich RG, J. Virol. 84, 459-474, 2010. http:// dx.doi.org/10.1128/JVI.01226-09

Sibold C, Sparr S, Schulz A, Labuda M, Kozuch O, Lysý J, Krüger DH, Meisel H, Virus Genes 10, 277-281, 1995. http:// dx.doi.org/10.1007/BF01701817

Sibold C, Meisel H, Krüger DH, Labuda M, Lysy J, Kozuch O, Pejcoch M, Vaheri A, Plyusnin A, J. Virol. 73, 667-675, 1999a.

Sibold C, Meisel H, Lundkvist A, Schulz A, Cifire F, Ulrich R, Kozuch O, Labuda M, Krüger DH, Am. J. Trop. Med. Hyg. 61, 409-411, 1999b.

Sibold C, Ulrich R, Labuda M, Lundkvist A, Martens H, Schütt M, Gerke P, Leitmeyer K, Meisel H, Krüger DH, J. Med. Virol. 63, 158-167, 2001. http://dx.doi.org/10.1002/10969071(20000201)63:2<158::AID-JMV1011>3.0.CO;2-\#

Song JW, Baek LJ, Song KJ, Skrok A, Markowski J, BratosiewiczWasik J, Kordek R, Liberski PP, Yanagihara R, Virus Genes 29, 239-247, 2004. http://dx.doi.org/10.1023/ B:VIRU.0000036384.50102.cf

Song JW, Gu SH, Bennett SN, Arai S, Puorger M, Hilbe M, Yanagihara R, Virol. J. 4, 114, 2007a. http://dx.doi. org/10.1186/1743-422X-4-114

Song JW, Kang HJ, Song KJ, Truong TT, Bennett SN, Arai S, Truong NU, Yanagihara R, Emerg. Infect. Dis. 13, 1784-1787, 2007b. http://dx.doi.org/10.3201/eid1311.070492

Sumibcay L, Kadjo B, Gu SH, Kang HJ, Lim BK, Cook JA, Song JW, Yanagihara R, Virol. J. 9, 34, 2012. http://dx.doi. org/10.1186/1743-422X-9-34

Tamura K, Peterson D, Peterson N, Stecher G, Nei M, Kumar S, Mol. Biol. Evol. 28, 2731-2739, 2011. http://dx.doi.org/10.1093/ molbev/msr121

Vapalahti O, Lundkvist A, Kukkonen SK, Cheng Y, Gilljam M, Kanerva M, Manni T, Pejcoch M, Niemimaa J, Kaikusalo A, Henttonen H, Vaheri A, Plyusnin A, J. Gen. Virol. 77, 3063-3067, 1996. http://dx.doi.org/10.1099/0022-1317$\underline{77-12-3063}$

Weiss S, Witkowski PT, Auste B, Nowak K, Weber N, Fahr J, Mombouli JV, Wolfe ND, Drexler JF, Drosten C, Klempa B, Leendertz FH, Kruger DH, Emerg. Infect. Dis. 18, 159-161, 2012. http://dx.doi.org/10.3201/ eid1801.111026

Zelena H, Zvolankova V, Zuchnicka J, Liszkova K, Papa A, J. Med. Virol. 83, 496-500, 2011. http://dx.doi.org/10.1002/ jmv.21984 